\title{
Sustainable use of natural resources in the Arctic region (the example of China's cooperation with Western countries)
}

\author{
Tatiana Batova ${ }^{1}$,Ekaterina Lazareva ${ }^{1}$, and Elena Pavlova ${ }^{1, *}$ \\ ${ }^{1}$ ITMO University, Kronverksky pr., 49, Saint-Petersburg, Russia
}

\begin{abstract}
The relevance of this study is caused by the need to solve problems of sustainable use of natural resources in the Arctic region when implementing projects with international participation. The paper highlighted a number of the most significant problems of the region, which destroy the ecological balance. The areas of development of the natural resources of the Arctic region have been determined with the participation of countries interested in this, in particular, China, which is striving to become the leading export world power and influence the sustainable use of natural resources in the Arctic region. The paper analyzes the interests of China in the Arctic, identifies the strategy of China's behavior and the main directions of international cooperation with the countries of Northern Europe and North America in the Arctic region. China is increasingly pursuing its Arctic policy, and international cooperation is an important way for China to strengthen its research and economic potential in the Arctic. The dominant interests of China in the Arctic are: the development of polar scientific research; the creation of a transport and logistics system; development of hydrocarbon energy and mineral resources; development of systems based on renewable energy sources; maintaining ecological balance, including through the development of a green economy in the region; environmental protection. In this regard, China is taking active steps to establish strong bilateral and multilateral relations with Western countries, the so-called Arctic G8 countries, and seeks to promote its interests in the region under consideration, including through large investments in the Arctic projects of these countries.
\end{abstract}

\section{Introduction}

In recent years, the Arctic region has attracted increasing global attention. In addition to traditional participants, countries that are far from the polar latitudes have joined the struggle for dominance in the region. These new participants consider the Arctic, first of all, as an important element of the two systems: transport and energy. Since 2013, Asian countries have noticeably increased their interest in Arctic policy. This is caused by the fact that a number of countries (China, Republic of Korea, India, Japan, and Singapore) obtained the status of observer in the Arctic Council. Among the countries remote from the

\footnotetext{
*Corresponding author: eapavlova@corp.ifmo.ru
} 
Arctic region, but seeking to influence the Arctic policy, it is necessary to highlight the People's Republic of China. It is China that more than other countries is interested in the resource potential of the region, is taking active steps to establish strong bilateral and multilateral relations with the so-called Arctic G8 countries, and is striving to promote its interests in the region under consideration. However, the development of international activities in the Arctic region is substantially limited by the need to ensure the ecological balance of this zone, since an ill-considered approach to the implementation of projects for the development of the natural resources of the Arctic can seriously degrade the environment, lead to the destruction of plants and animals, and pose a threat to the existence of indigenous inhabitants.

Today, the environmental problems of the Arctic are no longer purely regional and are becoming international issues that attract the attention of not only the government of the Russian Federation but also the international community.

\section{Materials and Methods}

Official government decrees, laws, bilateral and multilateral agreements of various states, and also various agreements between research institutes and business companies of different countries were considered as the sources of information. The paper uses general scientific research methods. When studying the Arctic interests of China, a comparative descriptive method was used. To determine the prospects and trends in the development of China's relations with the countries of the Arctic region, statistical information and a systematic method were used. Also, in the course of the study, such methods as the interdisciplinary method, comparative analysis and forecasting were used.

\section{Results and Discussion}

\subsection{Problems of environmental management in the Arctic}

The Arctic region is largely shaping the planet's climate, so the state of the environment in this region is crucial for studying climate trends in the whole world. The Arctic is called an "indicator of global climate change", which may have, in the first place, serious environmental consequences. This is due to the fact that for many decades, the problems of sustainable land use in the Arctic have not been given enough attention, and today, the Arctic region is saturated with both civilian and military facilities that pose a potential hazard to the environment. The bases of the civil and naval fleets, storage facilities for irradiated nuclear fuel, industrial wastes that accumulate around manufacturing facilities are located here. An additional danger is the pollution of the atmosphere of the Arctic by gas and aerosol impurities, pollution of the natural environment due to increasing development of territories. Industrial development and operation of facilities is not always carried out taking into account the principles of "green economy". It should be borne in mind that the prospects for the development of natural resources, such as mining of minerals on the shelves, can also seriously affect the preservation of ecological balance.

The ecological system of the Arctic region is quite vulnerable due to extreme nature and climatic conditions, significant dependence on the influence of anthropogenic factors that violate natural processes, and, as a result, the complexity of maintaining ecological balance. In recent years, the Russian Federation has begun to pay serious attention to this region: the collection of industrial waste near polar cities has begun, military equipment dumps have been eliminated, attention has been paid to solving legal and environmental problems. 
Today, the main objectives of the Russian Federation in the implementation of state policy in the Arctic region are defined in the "The Strategy of the Arctic zone of the Russian Federation development and national security system for the period till 2020" [1] and are both in the field of socio-economic development aimed at expanding region to meet the needs of the Russian Federation in hydrocarbon and other types of resources, and in the field of environmental safety, which is closely related to the solution of social and economic problems and is focused on the preservation and protection of the natural environment in the conditions of increasing economic activity and the elimination of environmental consequences resulting from irresponsible human activity.

International cooperation is essential for the preservation of the nature of the Arctic zone. The development of scientific research in the Arctic was largely promoted by the creation of the International Arctic Science Committee (IASC) - a non-governmental international scientific organization formed in 1990, which aims to support the cooperation of all countries participating in Arctic research and scientific projects aimed at preserving the Arctic ecosystem. The objectives of this organization are mainly focused on solving the problems of coordinating scientific activities of different countries, providing scientific information on the state of the ecological environment in the Arctic and ensuring its accessibility, providing scientific advice and grants in the form of scholarships to members of international working groups. In this case, the selection of researchers is carried out on a competitive basis. The areas of research are quite wide: from the study of the atmosphere and marine life to environmental problems. One of the important tasks is the problem of ensuring sustainable use of natural resources in the Arctic.

However, there are still a number of serious problems that have not yet received sufficient legal solutions. The territorial disputes between the countries of the Arctic region have not been settled yet, which hinders the investment of projects for the development of oil and gas reserves in these territories by international companies. There is no single position on the international legal status of the Arctic. The issues of delimitation of the borders of the continental shelf remain unsolved.

In modern conditions, the Arctic acquires a large role in environmental management, global politics and economics, and the Arctic region itself is becoming the object of close attention of leading Arctic states and countries that intend to become the leading global export powers and influence the development of the Arctic region. One of these countries is China.

\section{Interests of China in the Arctic}

According to L. Smith, soon the economic and political center will finally move towards the New North [2]. The vector of confrontation "West-East" is changing to "NorthSouth". It reflects not only the concept of the rich North and the poor South, but also considers such a factor as the shift of trade and economic routes to the North [3]. Since the Arctic ice continues to collapse, international debates on potential trade routes are focused on three potential waterways, namely, the Northeast Passage (which includes the Northern Sea Route along the Russian Arctic coast from the Barents Sea to the Bering Strait), Northwest Passage, and Polar Passage. The Northeast Passage connects Northern Europe with Northeast Asia, and is considered by many Asian countries, including China, as the best route to send goods to European markets. Melting of the Arctic ice will allow yearround transportation along the Northern Sea Route, which allows reducing the distance from Shanghai to Habsburg by $5200 \mathrm{~km}$, compared with the route through the Suez Canal.

Chinese professor Li Zhengfu wrote the following in 2009: "When the Northwest Passage will start to work, it will become the new "axial sea route" between the Atlantic and the Pacific Ocean. The one who controls the Arctic way will control the new corridor in 
the world economy and international strategy" [4]. In the light of these forecasts, China considers the Arctic as an important geostrategic region.

For a long time, the Arctic was considered by China only within the framework of research and development field and environmental research field. The first steps in the study of the Arctic by Chinese scientists were taken in the 1980s, since 1994, they began to study the Arctic basin. In 1989, the Polar Research Institute of China (PRIC) was founded. The Institute is located in Pudong (Shanghai) under the auspices of the Shanghai Institutes for International Studies (SIIS) and under the supervision of the State Oceanic Administration (SOA) of China. The Institute also provides international cooperation and academic exchange.

The initial goal of PRIC was to organize research projects in the polar regions. In 1995, a group of Chinese scientists and journalists embarked on a hike to the North Pole to study the ice cover, climate and environment. In 1993, China got its first icebreaker named "Snow Dragon" (Xuělóng). This non-nuclear icebreaker was built at the Kherson Shipyard in Ukraine. In 1999, China sent the first expedition to the North Pole by sea, which laid the foundation of a whole series of research projects. Another organization within the framework of SOA is the Chinese Arctic and Antarctic Administration established in 1981, which controls and organizes research projects at both poles.

Only in 2007, China's study of the Arctic went beyond environmental research. Of great importance for the development of political and economic tasks in the Arctic was the inclusion of an ambitious program for the development of polar scientific research for 2006-2010 in China's XI five-year plan [5].

Unlike the Arctic states, China does not have territorial sovereignty and associated sovereign rights to extract resources and fishing in the Arctic. Faced with very limited rights as a non-arctic state, China strived to develop a strategy to bridge the growing gap between legal and institutional constraints in the Arctic.

The transforming Arctic is fueling the competing claims of the Arctic states for territorial waters, as well as for the expansion of the continental shelf. Unresolved disputes between these states over maritime boundaries, jurisdiction and development of Arctic resources underscore the contradictory nature of existing Arctic legal mechanisms. UNCLOS, which entered into force in 1994, remains the most comprehensive international legal framework for managing the activities of states in the World ocean, including the Arctic Ocean. The United States is the only Arctic state that has not yet ratified UNCLOS, which, according to many Arctic observers, is weakening the USA influence in Arctic affairs. For China, the provisions of UNCLOS are the legal basis for China's activities in the Arctic. China recognizes that since it does not border the Arctic Ocean, it does not have sovereign rights in the region. In 2010, Assistant Foreign Minister Liu Zhenmin publicly supported UNCLOS as the main legal mechanism for activities in the Arctic.

A confirmation of the seriousness of China's ambitions in the Arctic is the China's Arctic policy published in January 2018. The document describes the Chinese vision of the region's economic potential. Besides, China has promised to actively participate in Arctic affairs as an "almost Arctic state" and a major party concerned in the Arctic. The document specifically addresses the respect and protection of the rights of the indigenous peoples of the Arctic, and also refers to environmental protection, scientific research, and international cooperation. China clearly indicates its intention to expand the scope of its activities in the Arctic in order to use the "historical opportunity" for various types of commercial activities. China recognizes for the first time that its arctic interests are no longer limited to scientific research. Commercial activities in the region are included in a new cooperation initiative led by China, which aims to create the "Polar Silk Road" connecting China with Europe through the Arctic. 
In the conditions of China's transformation into the leading export world power, due to the increase in the export potential of the economy, the transport and logistics factor is dominant among other aspects of China's economic interests. For the first time, the Chinese icebreaker "Snow Dragon" passed through the Northern Sea Route in 2012, and by 2020, according to Chinese long-term forecasts, from $5 \%$ to $15 \%$ of Chinese foreign trade cargo traffic mainly in the form of container traffic will follow this route [6]. Professor of Shanghai University Tongji V. Chunxing believes that "no country hopes to gain more than China from the development of maritime transport in the Arctic, because China's economy is half dependent on trade. The development of the Northern Sea Route would have a priceless impact on our economy. This is about a third of China's turnover with the EU and the USA. The opening of the Northern Sea Route is vital for China" [7]. Besides, China faces the problem of piracy in the Strait of Malacca. About $80 \%$ of China's imported fossil fuels must pass through the Malacca region, so alternative, politically more calm trade routes are of great interest to Beijing. Another no less important point related to the transportation vector of China's interests is the creation of the Northern Silk Road within the framework of the Silk Road Economic Belt concept. In addition to the South, China needs to create economic corridors ("silk roads") in the North for the successful development of China's trade and economic policy.

The growing economy and the standard of living of the Chinese population determines the country's need for a huge amount of resources. Melting of the Arctic ice contributes to the discovery of new mineral deposits. China is more interested in energy and mineral resources. According to estimates, 30\% of all global gas reserves and 13-15\% of the corresponding oil reserves are located in the Arctic (according to other expert estimates, the reserves of the North-Arctic shelf can even be up to $75 \%$ of all hydrocarbon reserves of the planet) [8]. In the conditions of an industrial economy and an extremely limited supply of natural resources, the wealth of the Arctic is of exceptional and vital interest for China.

In June 2014, a strategic assessment prepared by the National Defense Research Center at the Academy of Military Sciences of the People's Liberation Army (PLA) included notes on the Arctic as a key source of oil and gas, and also considered it as a route for transporting fossil fuels and other goods. There are suggestions that this region could become a "new Middle East" and provide a "new path of life" for China. As a result, it was concluded that the Arctic is on its way to becoming the main energy supply base for the Chinese economy, and that Beijing should seek partnerships with the states of this region [9].

Since the Arctic is the main region where the climate of the northern hemisphere is forming, including China, it is worth mentioning the country's environmental interests in the region. Chinese experts believe that global warming, in particular, the melting of the Arctic ice, is the cause of natural disasters in the country. It was repeatedly emphasized that the Arctic air passing over the territory of Siberia comes to China and brings a huge amount of precipitation that critically affects China's agriculture (for example, the tragedy in the south-western provinces of summer 2008 and the flood of 2012). Water exchange processes between the seas of the Arctic and the North Pacific directly affect the state and volume of marine bioresources in the coastal regions of China. This is a key aspect for Beijing to ensuring national food security. Therefore, it is crucially important for China to understand the situation and, if possible, influence the maintenance of the ecological balance in the region.

It should be noted that China respects the interests of the small-numbered peoples of the north. The development and use of resources in the Arctic are carried out taking into account the traditions and cultures of the Arctic inhabitants. China is promoting greater opportunities for improving educational and medical services in the region. The development and implementation of telemedicine systems is a key area in solving the 
problem of the remoteness of patients from medical care centers [10]. Such projects require significant investment support, and China, in turn, is the largest investor in Arctic projects from among non-Arctic countries.

China is taking measures to protect its key interests in the Arctic. These measures are: strengthening its ability to adequately respond to the effects of climate change in the Arctic; providing cost-effective access to arctic shipping routes; strengthening China's ability as a non-arctic state to gain access to Arctic resources and fishing waters.

As we can see, the interests of China in the Arctic are extremely diverse, but the question arises about the possibilities of realizing these interests. A strong and sustainable research potential in the Arctic is imperative for China to contribute and take a prominent position in the control of the Arctic. In general, China has very significant resources to realize its goals and potential in the Arctic. First, the economic power of China plays a huge role. This is followed by the leading position of the industrial complex of the country. The rapid development of manufacturing and transport industries directly affect the successful creation of a national transport and logistics system in the Arctic region. The overall capacity and technical resources of Chinese maritime shipping companies are steadily increasing, as well as their respective world rankings [11].

Polar exploration potential is key to any polar expedition. China is increasing its Arctic capabilities, as highlighted at the high-level polar research conferences. Over the past twenty years, investments in research and development, including research programs in the Arctic, have increase noteworthily in the country: supporting the operation of the Arctic Yellow River Station on Svalbard (Norway); construction of new research stations in the region; investment in the modernization of the northern seaports of the countries of the Arctic region; production of special equipment, including deep-sea robotic systems, drilling rigs and platforms [11].

\section{Cooperation with Northern European countries}

The most striking manifestations of China's efforts in the field of Arctic diplomacy are its relations with Northern European countries. It was the countries of Northern Europe that supported the interests of China in the Arctic, and also actively lobbied for China to join the Arctic Council. Such support is driven by the fact that, without having a leading position in the region, countries are interested in financial support from China.

On April 27, 2016, the European Commission published a message on the integrated EU policy on the Arctic, which proposes three priority areas: climate change and the protection of the Arctic environment; sustainable development in the Arctic and adjacent areas; and international cooperation on Arctic issues. The European Parliament adopted a resolution on the integrated EU policy on the Arctic in March 2017.

In May 2019, the seventh China-Nordic Arctic Cooperation Symposium will be held in Shanghai. Last year the Symposium was held in Norway. The main topics of discussion were: fishery management in Arctic waters, marine pollution, climate change, and sustainable development in the Arctic.

Of all the Arctic countries of Northern Europe, China has achieved the greatest success in relations with Iceland. The economic crisis of 2008 dealt a painful blow to Iceland, so it was more than anyone else interested in China's investments. Like Norway, Iceland has for many years lobbied China's accession to the Arctic Council as a permanent observer. In turn, China is attracted by the geographical position of Iceland, thanks to which the country can become an important center of Arctic logistics. China has already announced its desire to lease Iceland port facilities for long-term lease.

In April 2012, China's Prime Minister Wen Jiabao visited Iceland and Sweden. This was the first visit of a high-ranking Chinese leader to Iceland in 40 years. Wen Jiabao said 
the following about cooperation with Reykjavik: "Together with Iceland, the Chinese side intends to begin actively implementing the points on which the parties were able to achieve unity of opinion, expand the scope of cooperation in a number of areas, strengthen interaction in the framework of the activities in the Arctic region for the sake of joint development".

In 2012, during the visit of Wen Jiabao to Iceland, a number of agreements on bilateral cooperation between China and Iceland were concluded in a number of areas. Among other things, it was decided to establish the Sino-Nordic Arctic Research Center in Shanghai. In October 2013, a partnership agreement was signed between CNOOC (China) and the energy company Eykon Energy (Iceland) for joint exploration of oil and gas in the Draka region in the North Atlantic between Iceland and Norway (south-east coast of Iceland). It is worth noting that the study areas are adjacent to the island region of Jan Mayen on the Norwegian side of the sea border. In accordance with the agreement between Iceland and Norway in 1981 , both parties have the right to demand $25 \%$ in any exploration in the area [12]. Thus, the Norwegian company Petoro acted as the third partner, and the remaining $75 \%$ of shares were divided between CNOOC (60\%) and Eykon (15\%). In 2013, Iceland became the first European country to sign the Free Trade Agreement with China, the partnership between China and Iceland includes cooperation in the field of energy (geothermal energy, oil and gas), shipping, finance, and offshore production.

In 2016, the China Remote Sensing Satellite North Polar Ground Station (CNPGS) was built in Sweden. As the first Chinese terrestrial satellite receiving station, CNPGS has increased the efficiency of satellite data transmission and improved China's ability to access remote sensing data in the Arctic region.

Norway was one of the first to note the importance of the activities of non-Arctic states in the region. It was Norway that initiated the accession of China and other non-Arctic powers to the Arctic Council as observers. Sino-Norwegian relations of the Arctic orientation have begun back in 2004, with the construction of the first Chinese Arctic Yellow River Station on Norwegian Svalbard. Mutual support between China and Norway is reflected in the organization of joint scientific expeditions and research projects. In July 2014, it was announced that the Chinese Offshore Oil Engineering Company (COOEC) and the Norwegian engineering and construction company Kvaerner are starting work on a joint venture in the field of oil production [13].

In April 2018, the plans of Norway and China to expand cooperation in monitoring and forecasting the Arctic climate were announced. Scientists from the two countries conduct more research on how climate change in the Arctic affects the climate of Europe and Asia. It is expected that this cooperation will contribute to the study and understanding of the Arctic climate and environmental changes in China, as well as provide scientific support for the development of Arctic resources. The cooperation is based on the Nansen-Zhu International Research Center (NZC) platform created jointly by China and Norway in 2003. In December 2018, Norway opened the longest suspension bridge beyond the Arctic Circle. The $1.5 \mathrm{~km}$ long bridge was built in collaboration with the Chinese Sichuan Road and Bridge Group (SRBG). The Chinese company put steel structures and was responsible for the installation of the bridge, the construction of which took more than five years.

Denmark attracts the special interest of China due to the island of Greenland - the arctic part of the country. Greenland has wide autonomy, but the infrastructure of the largest island of the planet remains underdeveloped. The population of the island stand for complete independence from Denmark with regard to the energy resources of the Arctic. Also, Denmark has tense relations with its Arctic neighbors because of the disputed territories in the region. In addition, Denmark is the third country (after Russia and Canada), which declared its territorial claims to the North Pole. In this regard, the country needs an ally from among non-Arctic countries. China may be such an ally. 
A number of experts believe that Denmark is in dire need of Chinese investments for the development of Greenland and for the development of Arctic natural resources. In 2013, the intelligence risk assessment (Intelligence Risk Assessment 2013: An Intelligence Assessment of Developing Affecting Denmark's Security, Danish Defense Intelligence Service) took into account China's economic interests in Greenland, which indicated that more and more Chinese companies and banks were interested in potential investment in Greenland. Thus, a mining project at the Isua iron ore deposit (Greenland) receives large investments from the Chinese state corporation Sichan Xinue Mining. It is worth noting that the United States, like Russia, is very skeptical about China's attempts to secure control over the above mentioned deposit.

At trade fairs and during meetings with Chinese officials and large companies in the mining, construction, hydropower and engineering industries, Greenland, as a rule, is actively trying to attract Chinese investors and contractors to participate in their projects. China sees Greenland as a strategic place for the long term investment. However, this dependence on economic support does not reduce Denmark's caution regarding China's expansion of its presence in the region. Do not forget that Copenhagen seeks to obtain special priorities in the region as a country of the Arctic circle, which is contrary to the interests of Beijing.

Finland. In February 2017, the Minister of Foreign Affairs of Finland Timo Soini visited China to strengthen relations between the two countries, including on the development of the Arctic region. And in April of the same year, the head of China Xi Jinping visited Finland. According to him, "China and Finland are working to create a new, future-oriented type of partnership. It will open up tremendous opportunities to expand our relationship".

In April 2018, China and Finland signed an agreement to establish a joint research center for space observation and data exchange services in the Arctic. The countries agreed to create a center as a platform for international scientific cooperation in the Arctic region. The research center will be built in northern Finland in Sodankylä, Northern Lapland. The center will expand cooperation in the field of cryosphere research using satellites that will provide information for use in climate research, environmental monitoring, and navigation in the Arctic Ocean.

A number of experts believe that Finland is a strategically important partner of China for ensuring its positions in the Arctic, the EU, and also in the field of high technologies. Beijing also hopes that the Finnish government will take part in the creation of the "New Silk Road".

\section{Cooperation with North American countries}

Perhaps, more than other Arctic countries, Canada is concerned about China's growing ambitions and intentions in the region. Canada takes a tough stance on the participation of non-Arctic countries in Arctic affairs. First of all, Canada perceives China in the Arctic as a threat to its sovereignty. Moreover, China claims the resources of the Canadian Arctic, and, as mentioned above, seeks to internationalize the northern sea lanes and to use the Northwest Passage, which crosses the Canadian territories.

It is possible to observe China's growing interest in the joint development of Arctic oil and gas. In February 2013, China National Offshore Oil Corporation (CNOOC) completed the acquisition of Canadian energy company Nexen. The $\$ 15.1$ billion deal not only strengthened China's interests in the potentially profitable oil sands of northern Alberta but also led to tighter rules in Ottawa regarding the purchase of oil sand assets by foreign stateowned enterprises because of concerns that other governments gain too much control over the main Canadian resource. By 2014, Chinese companies had invested more than $\$ 30$ 
billion in the Canadian energy industry. As Professor Rob Hubert of the University of Calgary notes, "behind these large-scale Chinese investments, there is Beijing's intension to ensure direct access to the Arctic resources" [14].

Recently, China and Canada have been actively cooperating on the development of renewable energy sources. In November 2018, Jason Krips, Deputy Minister of Economic Development and Trade of the Government of Alberta (Canada), emphasized that Canada and China share an interest in developing a green economy. A third of global investment in the development of renewable energy comes from China.

Thus, Canada's position on China's Arctic policy is ambiguous. Being interested in direct Chinese investment, Canada intends to limit China's political presence in the Arctic. At the same time, China has certain "trumps" in the development of relations with Canada regarding the Arctic. This is a large Chinese diaspora in the country (Chinese is the third most common language in Canada), which creates a certain Chinese lobby in Canadian public and business circles [7].

The USA presidency in the Arctic Council in the period up to May 2017 gave the USA the opportunity to develop a joint strategy with China on a variety of Arctic research and political issues. The Arctic is becoming an important testing ground for USA-China relations. The USA, being the most powerful nation in the world, is forced to settle for minor roles in the Arctic, because, firstly, the USA did not ratify the Convention on the Law of the Sea (1982), and secondly, the Arctic territory of the USA is much smaller than Canadian and Russian. Under these conditions, the USA relationship with China on the Arctic is becoming an important factor in strengthening its position in the region [7].

Since 2010, China and the USA have begun an annual dialogue on the law of the sea and polar issues within the framework of a strategic and economic dialogue. Compliance and future application of the International Code for Ships Operating in Polar Waters (the Polar Code entered into force on January 1, 2017) is a matter of national interest for both maritime states. Bilateral cooperation could also include the identification of a range of marine conservation measures, such as marine protected areas, as well as exploring how these measures may depend on future commercial shipping in the Arctic Ocean.

Compliance with maritime laws, especially those related to fishery, in the northern waters is of practical and operational importance. The USA and China already have experience in this area due to the joint work in the Pacific Ocean. The agreement signed in July 2015 by the five littoral states of the Arctic Ocean (Canada, Denmark, Norway, Russia, and the USA) in Oslo on the prevention of unregulated fishing in the central Arctic Ocean will certainly require the participation of non-Arctic states such as China. Involving China in the early stages of discussing fisheries in the Arctic on a bilateral basis with the USA or between Arctic states can be an effective strategy to minimize future disagreements.

Moreover, the issue of Arctic fisheries was included in the eighth special joint conference on climate change between the USA and China. Washington's initiative to regulate fisheries in the central Arctic Ocean was confirmed at a bilateral meeting between Barack Obama and Xi Jinping during the G20 Summit in Hangzhou in September 2016.

Another point of contact between the interests of China and the USA is China's intentions to internationalize the Northwest Passage, which coincides with the intentions of the USA regarding this sea route. The international legal status of the passage is controversial, and Ottawa argues that the route entirely consists of Canadian historic inland waters, while the USA considers the passage to be international as intended. In January 1988, an Agreement on Cooperation in the Arctic was signed between Washington and Ottawa, confirming that the USA would request Canada's permission about the presence of American icebreakers in the passage [15]. However, thanks to the use of the "unbiased position", the document left untouched the issue of sovereignty of Canada, and whether the 
United States recognized the passage as Canada's inland waterway, leaving the issue unresolved.

It should be noted that the territory of the Arctic zone, being a unique ecological system with a complex natural climatic zone, at the same time, creates a whole range of political and economic projects and opportunities in which many states are interested [16].

\section{China in regional arctic organizations}

The most influential international intergovernmental organization in the region is the Arctic Council established in 1996 to serve as a forum for cooperation and coordination between the eight Arctic states (Russia, the USA, Canada, Iceland, Norway, Denmark, Finland, Sweden) and the indigenous peoples of the region.

For the first time, Beijing expressed interest in obtaining observer status in the Arctic Council in 2007 after a meeting of the Senior Arctic Officials (SAO) in Troms (Norway). China's application for observer status in the Council was rejected in 2009, largely due to internal disputes between eight member countries on how to ensure that new observers such as China, Japan and the European Union could participate as observers, but would not have the possibility to change the nature of the organization itself. Some governments in the countries of the Arctic region, especially Canada and Russia, were concerned that there were more new observers than permanent members of the Council. And only in May 2013, China finally received observer status in Kiruna (Sweden).

With regard to the China's observer status in the Arctic Council since 2013, China, in accordance with the Ottawa Declaration of the Arctic Council in 1996, recognizes:

a) the sovereignty of the Arctic states, their sovereign rights and jurisdiction in the Arctic;

b) regulation of relations in the Arctic Ocean on the basis of a broader legal framework, including international law of the sea;

c) the values, interests, culture, and traditions of indigenous peoples and other people of the Arctic [5].

China cannot claim to become a permanent member of the council, since it has no territory beyond the Arctic Circle. Nevertheless, there are arguments in the country that China's proximity to the Arctic region and the emerging climate change effects in the region justify China's active participation in discussions regarding the Arctic. Beijing emphasized that its priorities in the Council are to continue scientific and environmental research in the region, and also to develop trade routes and facilitate the development of resources in the Arctic.

Even before obtaining the observer status in the Arctic Council, China was actively involved in international Arctic processes. The formation of numerous regional platforms with the participation of East Asian countries allows China to actively participate in the discussion of issues of Arctic policy and cooperation.

In 1991, the Northern Forum was created - an international non-governmental organization of the northern regions. China's Heilongjiang Province is a member of this organization. Back in 1996, China joined the International Arctic Science Committee, becoming the sixteenth member country of the organization. In 2005, China organized the Pacific Arctic Group as part of the International Arctic Science Committee. In the same year, China was admitted to the Ny-Ålesund Science Managers Committee. China also joined and actively participated in the events of the International Polar Year 2007-2008. Since 2011, the annual conferences of the North Pacific Dialogue "The Arctic in World Affairs" have been held, in which China actively participates.

Chinese scientists have also joined foreign Arctic research expeditions and started programs of exchange and cooperation with Arctic research centers around the world, including the University of Alaska, the University of Washington, the International Arctic Research Center, and the Korea Maritime Institute. China takes an active part in the work 
of the annual Arctic Circle Assembly created in 2013 to bring together non-Arctic countries and all interested participants to discuss topical Arctic issues.

In December 2013, the China-Nordic Arctic Research Council (CNARC) was officially opened in Shanghai. It unites Arctic Studies Centers in Northern Europe as well as Chinese institutions, including SIIS, PRIC, the Polar Law and Politics Research Center (Qingdao), and the Center for Polar and Ocean Studies at Tongji University (Shanghai). In October 2015, at the Arctic Circle Assembly in Reykjavik, Chinese Deputy Foreign Minister Zhang Min emphasized that China is a large participant in the Arctic, and is ready and can make a great contribution to the sustainable development of the region. China expressed its willingness to move away from the role of a passive observer and fully engage itself in Arctic issues, while reaffirming its commitment to respectful, cooperative relations with other actors in the region.

\section{Conclusion}

In recent years, China has been actively expanding its presence in the Arctic region. In its Arctic strategy, China unequivocally states its position on the issue of the Arctic openness. According to China, the Arctic should belong to the world community, and not just a group of Arctic countries. Through its research and political activities, Beijing pursues a number of objectives.

Firstly, China seeks to gain access to raw materials (including fossil fuels, minerals and metals), which may become more easily accessible due to the retreating ice. Secondly, China is interested in using the Arctic sea routes, especially the Northern Sea Route. Passing through the northern Siberian coast is of great interest to Beijing, since it seeks to export goods to Europe and beyond using faster and less expensive routes. Thirdly, a significant portion of China's attention in the Arctic region is based on scientific interests, including research in geography, climatology (especially climate change), geology, and oceanography.

China is one of the few countries with both financial resources and potential labor force to participate and conduct various international projects in the Far North. At this stage, China lacks the technical base for the independent implementation of Arctic projects, but the government is actively funding the development of this industry.

International cooperation is an important way for China to strengthen its influence in the Arctic. Beijing has expressed interest in developing partnerships with the Arctic states in various fields. However, China's growing claims and increased participation in Arctic affairs are worrying its partners in the region, who are skeptical about the ideas of internationalization of the Arctic. Beijing seeks to increase the potential of diplomatic and scientific cooperation to ensure its right to vote in the emerging issues of global governance related to the Arctic.

Over the past decade, China has made a number of successful attempts to strengthen its influence in the Arctic, obtaining observer status in the Arctic Council, as well as expanding broad economic and research activities in the region.

Thus, China is playing a challenging diplomatic game in which, on the one hand, it is trying to carry out the idea of internationalization of the Arctic region among non-Arctic countries, and on the other hand, seeks to enlist the support of small Arctic countries, investing huge sums in their Arctic projects. Thus, it actively participates in solving problems of preserving the natural resources of the Arctic. Based on the China's Arctic policy published in 2018, it can be assumed that China is not satisfied with the current agreements with the Arctic countries and therefore calls for the strengthening of international cooperation between the Arctic and non-Arctic states. This means that in the coming years, the topic under study will receive a new impetus to development. 


\section{References}

1. http://legalacts.ru/doc/strategija-razvitija-arkticheskoi-zony-rossiiskoi-federatsii-i/ (Last accessed 13.03.2019)

2. L. C. Smith, The New North: the World in 2050. London: ProfileBooks, (2011)

3. M. L. Lagutina, Arctic Transit: Prospects for Russia, Annual Russian-American Seminar at St. Petersburg State University. Papers and speeches of participants of the XXII seminar (Saint-Petersburg, Publishing house of St. Petersburg State University, 2013)

4. V. V. Karlusov, Arctic vector of globalization of China. Arctic region: Problems of international cooperation: Chrestomathy in 3 volumes / Rossian Council on international affairs [ed. I.S.Ivanov]. (Moscow, Aspect-Press, 2013)

5. V. S. Yagya, N. K. Kharlampyeva, M. L. Lagutina, Arctic - a new region of China's foreign policy, Bulletin of Peoples' Friendship University of Russia. Series: International Relations, 1, 43-52 (2015)

6. http://inosmi.ru/fareast/20130316/207029398.html (Last accessed 27.03.2019)

7. https://disser.spbu.ru/disser2/disser/ (Last accessed 25.04.2019)

8. V. V. Karlusov, Arctic in the system of global priorities of Beijing: a view from Russia, MGIMO Review of International Relations 5, 24-32 (2012)

9. M. Lanteigne, China's emerging Arctic strategies: economics and institutions, University of Iceland Press, 68 (2014)

10. A. I. Lyovina, I. V. Ilyin, D. F. Skrypnyuk, The possibilities of digital technologies in the implementation of telemedicine systems in the Arctic zone, Global scientific potential. 2(83), 74 (2018)

11. V. V. Karlusov, Arctic in the system of global priorities of Beijing: a view from Russia, MGIMO Review of International Relations, 5, 24-32 (2012)

12. Agreement between Iceland and Norway on the Continental Shelf in the Area between Iceland and Jan Mayen,' National Energy Authority of Iceland, 22 October 1981

13. Norway's Kvaerner, China's COOEC Form Joint Venture,' Energy Monitor Worldwide, 2 July 2014

14. https://regnum.ru/news/polit/1692453.html\#ixzz336T4SXoZ (Last accessed 14.04.2019)

15. https://treaties.un.org/doc/publication/unts/volume\%201852/volume-1852-i-31529english.pdf (Last accessed 19.04.2019)

16. I. M. Zaychenko, I. V. Ilin, A. I. Lyovina, Enterprise Architecture as a Means of Digital Transformation of Mining Enterprises in the Arctic. Proceedings of the 31st International Business Information Management Association Conference (IBIMA) 4652-4659 